\title{
An Influence of Knowledge Management to the Intellectual Capital and the Effect to the Competitive Advantage
}

Dian Indiyati*

Departement of Management, Faculty of Economics, Jenderal Achmad Yani University, Cimahi, Indonesia

*Corresponding author: dianinds@yahoo.com

\begin{abstract}
The extremely intense competition in education requires each Private Universities to have competitive advantages, where one of them is high intellectual capital, which can provide value to its customers. One of the influencing factors in the improvement of intellectual capital is namely the existence of effective knowledge management activities on PTS. This research intends to examine and analyze the effect of knowledge management on the intellectual capital, and the influence of intellectual capital on competitive advantage in the private universities. The research methods applied the explanatory survey, causal relationship, and verification method. The research population is PTS Kopertis Region IV. The sampling technique uses proportional probability sampling, where the sample size was determined by using power analysis approach test. Data collection was carried out by interview, observation, and questionnaire techniques that have been tested for validity and reliability. The analytical test applied SEM (Structural Equation Model)-LISREL 8.3, the second-order approach. The research result concluded that knowledge management has a significant impact on intellectual capital, intellectual capital has a significant impact on competitive advantage, and knowledge management significantly influences competitive advantage on the PTS through its intellectual capital.
\end{abstract}

Keywords: Competitive advantage; intellectual capital; knowledge management

(C) 2016 Penerbit UTM Press. All rights reserved

\subsection{INTRODUCTION}

The developments of Indonesian universities internationally have not been able to optimally compete. Data revealed by the Webometrics (2013), the state universities (PTN) entered the Top 500 in the world rankings, meanwhile private universities (PTS) ranked the top 1300 in rankings, and PTS Kopertis Region IV ranked above 3000.

The occurred phenomenon was that about 30\% PTS in Indonesia has been closed, due to its inability to compete with other universities, including the PTN (Kompas.com:2008). This is supported by a statement from the Wayah (Aptisi Secretary General) that the PTS cannot operate anymore because it cannot adapt to public demand. It issuspected that the closed PTS have not been optimally creating and innovating. Meanwhile, to be capable to intensely compete, it needed creativity and innovation, such as the establishment of a special curriculum that is tailored to the demands, so as to produce graduates who are guaranteed needed by employers. PTS also must be able to establish centers of excellence in its campus (Akhmadi, 2008).

The occurred reality was that the PTS lecturers' productivity is not optimal. Among others, this occurred because there has not been many production of lecturer's research results, academic papers, research publications, articles, textbooks, and call for papers nationally and internationally (Director General of Higher Education, 2009). Furthermore, based on the researcher's interviews with the PTS (2010), only certain lecturers carry out researches, academic papers, research publications, and articles. This is thought to result in the majority of scientific journals from the PTS Kopertis Region IV cannot be published according to the determined schedule. It is also evident that the accredited journals of Kopertis Region IV are only about 1.4\% (Indiyati, 2012).

The problems that are in Kopertis Region IV (2009) are the majority lecturers' level of education have not met the standard according tothe Law No.14 Year 2005 on teacher and lecturer, i.e. at least have graduated from a master degree program. In addition, the lecturers' productivity is not maximized and it has minimum orderly administration because of the ineffective system information causes PTS to not optimally perform networking with local government, industries, professional associations and high schools (Indiyati, 2012).

Based on the problems outlined above, it is an interesting matter to be studied researched in the form of a research on the influence of knowledge management to the intellectual capital and its impact on competitive advantage, where the problem is focused on the PTS Kopertis Region IV. The research intends to examine and analyze the effect of knowledge management on intellectual capital, as well as the influence of intellectual capital on competitive advantage on the PTS Kopertis Region IV. 


\subsection{THEORETICAL FOUNDATION OF THE STUDY}

\section{Knowledge Management}

Some meaning of knowledge management is presented as follows. According to Gregory (2010), knowledge management is the discipline of enabling individuals, teams and entire organization to collectively and systematically capture, store, create, share and apply knowledge, to better achieve their objectives. Furthermore, Carlucci et al (2004) states that knowledge management consists of processes that facilitate the development and implementation of organizational knowledge, to create more value for customers, and increase competitive advantage.

These concluded that knowledge management is a knowledge-based management process with the goal to create instruments and environments supporting the creation process (knowledge creation), sharing, storing, applying, and protecting knowledge in an organization.

In order that the knowledge management to work effectively, it should pay attention to four essential knowledge processes according to Hsu (2006) and Nguyen (2004), namely: knowledge acquisition (collecting knowledge, finding new knowledge, and redesigning knowledge); knowledge conversion (the ability to detect knowledge so that it becomes more useful); knowledge application (effective knowledge storage and uptake, and quick access of stored knowledge); and knowledge protection (protecting knowledge in an organization from any illegal act). In another opinion, there are three knowledge management processes (Dalkir, 2005):

1. Knowledge Creation. Knowledge creation can be done through creating new products, new services, new procedures, new processes, new jobs, new systems, and new regulations, and also to improve process (Hsu, 2006 and Birkinsaw, 2002).

2. Knowledge Transfer/Knowledge Sharing. Knowledge transfer is the process through which an individual, team, department or division is affected by the experience of another (Noe, 2003). Knowledge sharing activities may include workshops, seminars, town meetings and mentoring sessions, where those activities can improve the organizational performance (Szulanski, 2003). The knowledge sharing process undergoes through four phases: Socialization, Externalization, Combination, and Internalization (SECI). SECI is a continuous process, which can encourage the knowledge creation through the vertical and horizontal interactionsby means of exchanges between individuals, between sections, between departments, and even between organizations (Noe, 2003; Nonaka, 2007).

a. Socialization: a tacit knowledge sharing between individuals. Sharing can be done through direct experience, such as spending time together in completing the work, internships, day-to-day social interactions, coaching or following training, and formal and informal meetings to exchange ideas, experience and expertise of employees.

b. Externalization: a conversion process of tacit knowledge into explicit knowledge through the process of documenting, such human resources ideas or expertise into written form (Aulawi, 2009).

c. Combination: an exchange of explicit knowledge through the sharing of documents, procedures, or policies.

d. Internalization: an implementation process of explicit knowledge carried out together by the employees. It can be done through simulations, action learning and experience in the workplace, and can also be spread through the stories or narrations of work experience and relationships between colleagues, customers, managers and mentors (Noe, 2003).

3. Knowledge Utilization.This can also be interpreted as the knowledge application. It is in the form of document management, groupware, and E-Learning (Syaiful, 2007).

Based on the description above, it can be stated that the knowledge management process consists of creating, sharing, storing and applying, as well as the protecting knowledge.

\section{Intellectual Capital}

An Intellectual capital is the collective knowledge of the individuals in a society or organization. This knowledge can be used for competitive advantage of the company. It includes customer capital, intellectual property, human capital and structural capital (www.ask.com.Q\&A.Business).

According to the Klein and Prusak (in Stewart 1994), “...we can define intellectual capital operationally as intellectual material that has been formalized, captured, and leveraged to produce a higher valued asset”. Intellectual capital is the knowledge, experience, company processes, technology and customer relationships, and professional skills that are valuable assets for the organization (Pike, 2002). As a matter of fact, most researchers on intellectual capital agreed that intellectual capital is a critical firm resource. Intellectual capital is the intellectual materials that can be captured as assets, such as knowledge, information, intellectual property, and employees' experiences, commitments, or capabilities. These assets may increase a firm's performance, and they may in turn translate into a competitive advantage if some important assets are "immobile". (Barney, 2002; Bontis, 2002)

This concluded that intellectual capital is an intangible company asset that can provide value added to customers, which is a combination of human factors, processes/structures, and customers, and also can create a competitive advantage for the company.

Moreover is the classification of intellectual capital based on Zuhal (2010):

1. Human capital consists of implicit knowledge (education and competence), skills (skills that correspond to areas of competence), soft skills (such as lobbying, leadership, entrepreneurial spirit, managerial, networking, and areas of expertise of each sciences), and attitude (honesty, responsibility, visionary, discipline, cooperative, fair, caring, struggling spirit, and perseverance).

2. Structural capital consists of explicit knowledge (journals, research results, patents, articles, research papers, publications, and competitions), and process (ICT infrastructure, working system matrix, computerization, and information system management).

3. Relational capital consists of networking (external cooperation, partnership, and presence in various national and international events), reputation (awards, and recognition), and customer (university alumni, bureaucrats, government, industries, research institutes, and financial institutions). 
Competitive Advantage

Dessler (2007) argued "competitive advantage is any factor that allow an organization to differentiate its products or services from those of its competitors to increase of market share". According to Noe et al (2010), competitive advantage is a company's ability to offer a make product or services that are valued by customers more than those of competing firms.

Subsequently, it can be stated that the competitive advantage is a company strategy designed to create something new and different, which cannot be imitated by competitors, and rewarded with better value and accepted by the market that can be done through innovation, quality and cost strategies.

Competitive strategies that can be used by organizations to achieve competitive advantage are popularized by Porter (1985) as follow:

1. Innovation Strategy. Innovation is defined as the (product/service innovation) changes offered by company to a wide audience, as well as ways to create and deliver the changes (process innovation). The company's innovation capabilities include product/service innovation (i.e. the ability of the company to offer a differentiation or new product or service in a market and gain customer satisfaction); then process innovation (i.e. the ability of the company to produce a better manufacturing or service process than the current process; and last is management innovation, i.e. the ability of the company to improve its performance through the implementation of regulations, systems and new managerial methods (Liao et al, 2007).

2. Service Quality Strategies. The meaning of quality in this research is the service quality, because the research object is the university, which is engaged in the service sector. Service quality refers to the concept expressed by Kotler (2010), namely Tangible, Empathy, Reliability, Responsive, and Assurance. Tangible is the physical appearance, which can be physical facilities such as equipment. Empathy is caring and understanding customer needs. Reliability is the ability to provide services immediately, accurately and satisfactory. Responsive is providing service with fast or perceptive response. Assurance is trustworthiness or able to provide certainty.

3. Cost Strategy. The characteristics of a company carrying cost strategy are the existence of strict controls, overhead minimization principle, and the achievement of economic scale.

Based on the various concepts explained above, the research hypothesis can be stated : Those are knowledge management influences intellectual capital, and intellectual capital influences competitive advantage on private universities.

\subsection{METHODOLOGY}

The method applied in this research is an explanatory survey method. The type of research investigation is the causal relationship. The nature of research is research verification. The unit of analysis in this research is the organization. The research population are Private Universities. The sampling technique used is proportional probability sampling, where the sample size was determined by using power analysis approachpower test, in order to obtain samples totaling 157. The respondents are the vice dean or head of department, vice rector or dean, and students. Data collection was arranged by applying the techniques of interview, observation and questionnaires that have been tested for validity and reliability. Analytical testing of this research uses the Structural Equation Model (SEM)-LISREL 8.3, with the second order approach. Different from regression analysis, one advantage of using SEM is that it has some endogenous variables (dependent) and these endogenous variables can become exogenous variables (independent) to other endogenous variables (Hair, 1995:662).

\subsection{RESULTS AND DISCUSSION}

\section{Validity Test and Reliability Test}

All statement of the items that were used to measure the three variables are already valid so that they can be used for the next stage of analysis, because all validity indexes is higher than critical value 0.30 . Next, all statement items are reliable, because reliability coefficients are higher than 0.70 .

\section{Testing Assumption in SEM}

To run SEM analysis, it is necessary to run Normality Testing and Goodness of Fit Model Testing in advance. Below is the result of normality testing (table 1) and goodness of fit model testing (table 2):

Table 1. Multivariate normality testing result

\begin{tabular}{|c|c|c|c|c|c|c|c|}
\hline \multicolumn{8}{|c|}{ Test of Multivariate Normality for Continuous Variables } \\
\hline & kewness & & & Kurtosis & & Skewness an & d Kurtosi \\
\hline Value & Z-Score & P-Value & Value & Z-Score & P-Value & Chi-Square & P-Value \\
\hline 770.545 & 31.396 & 0.000 & 2193.409 & 13.674 & 0.000 & 1172.708 & ----- \\
\hline
\end{tabular}

Manifest variable data (indicator) does not distribute normal multivariate, because in the multivariate normality testing, the chi-square value is 1172.708 with p-value 0.000 ( the p-value is lower than 0.05 ). According to the data of normality testing result (non normal distribution), the compatible estimation method to be used to test the influence of knowledge management on intellectual capital and its effects on the competitive advantage is robust maximum likelihood method. 
Table 2 Goodness of fit model testing result

\begin{tabular}{|l|c|}
\hline \multicolumn{1}{|c|}{ Measurement of Goodness of Fit } & Estimated Value \\
\hline Chi-Square & $698.9505(\mathrm{p} \text {-value }=0.340)^{*}$ \\
\hline RMSEA & $0.0135^{*}$ \\
\hline Norm Chi-Square & $1.889^{*}$ \\
\hline GFI & 0.7639 \\
\hline AGFI & 0.7225 \\
\hline Root Mean Square Residual (RMR) & $0.0377 *$ \\
\hline
\end{tabular}

*) fulfilling criteria of good model

Goodness of fit is performed to determine whether the model has earned the right to describe the relationship between the variables being studied so that it can be categorized into good.

The calculation result of $\chi^{2}$ (chi-square) : this research model composed can be said be statistically compatible, because the value for the model observed is 698.9505 with p-value $=0.4444$. The fact that $p$-value is higher than 0.05 shows that $\chi^{2}$ testing is insignificant.

Based on RMSEA (Root Mean Square Error of Approximation) : the model fit the data perfectly, because the result of RMSEA for the observed model 0.0135 shows that the obtained model fulfills the criteria $(<0.10)$. The result of absolute compatibility measurement shows that the obtained model fulfills the criteria of goodness of fit on the RMSEA value which is relatively low $(0.0135<0.10)$ so that it can be concluded that the empirical model obtained is already compatible with theoretical model, which means that SEM model used in this research is appropriate and compatible.

Table 3 Influence of knowledge management on intellectual capital

\begin{tabular}{ccc}
\hline \multirow{2}{*}{$\begin{array}{c}\text { Endogenous } \\
\text { Constructs }\end{array}$} & Exogenous Constructs & \multirow{2}{*}{$\mathrm{R}^{2}$} \\
\cline { 2 - 3 } MI & 0.737 & 0.534 \\
& $(11.019)$ & \\
\hline
\end{tabular}

Note : Figures inbrackets are the t-test statistic value.

Table 4 Test of significance knowledge management-intellectual capital

\begin{tabular}{|l|c|c|c|c|}
\hline \multicolumn{1}{|c|}{ Variable } & Effect & t-value & t-table & Description \\
\hline $\begin{array}{l}\text { Knowledge Management- } \\
\text { Intellectual Capital }\end{array}$ & 0.737 & 11.019 & 1.975 & Significant \\
\hline $\mathrm{R}^{2}=0.534$ & & & \\
\hline
\end{tabular}

Table 5 Influence of intellectual capital on competitive advantage

\begin{tabular}{ccc}
\hline Endogenous & Endogenous Constructs & \multirow{2}{*}{$\mathrm{R}^{2}$} \\
\cline { 2 - 3 } Constructs & MI & 0.86 \\
\hline $\mathrm{KB}$ & 0.924 & \\
\hline
\end{tabular}

Note : Figures inbrackets are the t-test statistic value.

Table 6 Test of significance intellectual capital-competitive advantage

\begin{tabular}{|l|c|c|c|c|}
\hline \multicolumn{1}{|c|}{ Variabel } & Effect & t-value & t-table & Description \\
\hline $\begin{array}{l}\text { Intellectual Capital-Competitive } \\
\text { Advantage }\end{array}$ & 0.924 & 3.064 & 1.975 & Significant \\
\hline $\mathrm{R}^{2}=0.86$ & & & & \\
\hline
\end{tabular}




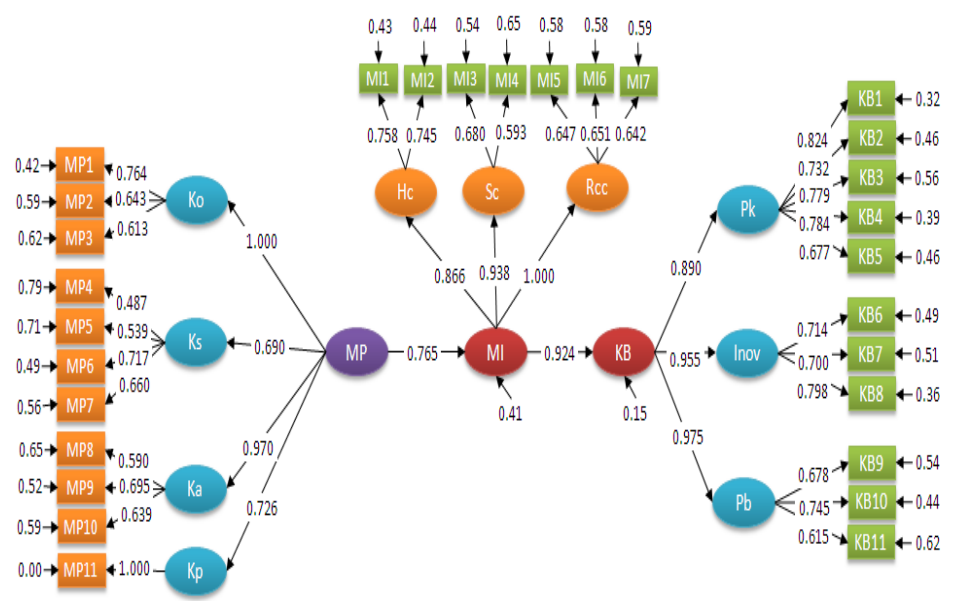

Figure 1 The influence of knowledge management to the intellectual capital and the impact to the competitive advantage on private universities (standardized coefficient)

\section{Influence of Knowledge Management on Intellectual Capital in Private Universities}

From the data processing by using the LISREL software, it was obtained the following results: the path coefficient from knowledge management to intellectual capital showed the value of 0.737 . Thus, it can be said that the amount of direct effect from knowledge management to intellectual capital achieved a 0.737 standard deviation, which means if there is an increase of one standard deviation in the knowledge management scale, thus the intellectual capital will then increase by a 0.737 standard deviation in the intellectual capital scale. The square from this value of $0.737^{2}=0.534$ or $53.4 \%$ stated the magnitude of change from the intellectual capital, which can able to be explained directly by knowledge management up to $53.4 \%$ (see Table 3 ).

After the path coefficient is calculated, to prove whether knowledge management significantly effect to the intellectual capital, a hypothesis testing is carried out. The result of statistical calculations on student t-test showed the value of t-value (11.019) is greater than the value of t-table (1.975), which means significant, thus it can be concluded that there is a significant influence on the knowledge management to the intellectual capital on the PTS Kopertis Region IV (see Table 4).

This can be implied that the PTS Kopertis Region IV performed knowledge creation, which aims to acquire knowledge in the form of distributing questionnaires to customers, benchmarking or comparative studies, inviting competent experts in their field, and facilitating the spread of knowledge to outside, i.e. the PTS channels ideas through writing in magazines with the aim that external parties know about the available knowledge in that PTS. This will result in PTS Kopertis Region IV to receive good cooperation from professional associations, government, national and international industries; to be able to follow many national and international call-for-papers; then the active contribution and input from alumni and graduate employers; and last to achieve a good reputation from external parties. Furthermore, if the PTS Kopertis IV can also create knowledge and knowledge sharing to outside (externalization) and also sharing knowledge through the lecturers' formal discussion about their own research through print and electronic media and through training, then PTS will obtain high structural capital in the form of explicit knowledge, namely high quality lecturers' researches, research papers, articles and text books. Finally, if PTS obtains grants from external institutions, it can also be used to improve the ICT infrastructure. If the PTS conducts training, it the employee competence increases. If PTS holds an informal meeting aimed at unity, such as doing sports together and morning coffee, it can increase the commitment of employees.

\section{Influence of Intellectual Capital on Competitive Advantage in the Private Universities}

Path coefficients of intellectual capital on competitive advantage show the value of 0.924 . Thus, it can be said that the amount of direct effect from intellectual capital to competitive advantage reached a standard deviation of 0.924, which means that if there is an increase of one standard deviation in the intellectual capital scale, thus the competitive advantage will increase by a 0.924 standard deviation in the competitive advantage scale. The square from this value of $0.924^{2}=0.86$ or $86 \%$ stated the magnitude of change of the competitive advantage, which can be explained directly by the intellectual capital, reached $86 \%$. This can also mean that intellectual capital can affect competitive advantage of PTS Kopertis Region IV by $86 \%$ (see Table 5).

Furthermore, other factor beside intellectual capital that influences competitive advantage on PTS Kopertis Region IV was $14 \%$. The other factor is tangible capital, which is the financial capital. This research result is in accordance to the opinion of Quink (2008) and Ramadan (2010) who stated that a company's competitive advantage is influenced by its intangible assets (intellectual capital) and tangible assets (financial capital). Another opinion expressed by Kuang et al (2010) who stated that a successful company is a company that gains profit derived from intangible assets, namely intellectual capital. Then Zhou and Dieter Fink (2003) argued that intellectual capital is an important resource for the survival of the company in achieving competitive advantage. Barney (2002) also argued that acompany may be superior in competition, when it several important assets of intellectual capital are well managed.

After the path coefficients are calculated, to prove whether the intellectual capital significantly influence competitive advantage, a hypothesis test is carried out. The results of t-test statistical calculations showed that the value of t-value (3.064) is greater than the value of 
$\mathrm{t}$-table (1.975), which means it is significant, and thus it can be concluded that there is significant influence from intellectual capital to the competitive advantage on the PTS Kopertis Region IV (see Table 6).

Therefore, in order for PTS Kopertis Region IV to create competitive advantage, it must pay more attention to intellectual capital. This can be done by improving the employee competence; improving education level, skills, and personal attributes; increasing its commitment; enhancing its structural capital, namely making its explicit knowledgemore qualified and ICT infrastructure more adequate; raising customer capital through good cooperation with professional associations, industries, and local governments; improving reputation; and finally increasing the customers' contribution, both from alumni and graduate employer. This is done in order that everything can create competitive advantage on PTS Kopertis Region IV, ranging from excelling in service quality, such as fast, accurate, satisfying, and responsive service; quality assurance of graduate, empathy, and facilities; excelling in innovation of its products, processes and management, and finally excelling in cost.

When the PTS Kopertis Region IV employees have high commitment and competence, such as the increase of academic advisor skills and academic staff skills, then it can improve the service quality to be fast, accurate, and satisfactory services, i.e. re-registration services, administrating academic transcripts, letters management, responsive to student demands, and empathy towards students. Moreover, the ability to create innovation/uniqueness in products, such as dual degree programs and process innovations in the form of the development of the PBM method, i.e.block system Competency-Based Curriculum (CBC), Student Center Learning (SCL), E-Learning, management innovation by using an adaptive organizational structure, and implementing an integrated management system, such as the implementation of TQM. Similarly, the availability of a complete ICT infrastructure in PTS Kopertis Region IV can operate the "automation". This can excel services to become fast, accurate, satisfying, and fast response; then it can excel products such as dual degree; also excel the process, such as application of SCL, E-Learning and CBC-block system; and finally excel in costs.

This is in accordance to the opinion of Dyer et al (2008) and of Schuller and Jackson (2008) who stated that in performing service quality strategy takes high commitment and skill of the employees and in performing cost strategy requires automation.

If PTS Kopertis Region IV performs good cooperation, namely with national and international professional associations, governments and industries, as well as actively obtain contributions from alumni and graduate employers, thus the PTS can run exceling programs featured in any PTS courses like the PTS dual degree. Carrying out the learning process (PBM) method development such as SCL, E-Learning and $\mathrm{CBC}$ can also provide a guarantee for the quality of its graduates where graduates are quick to find work as expected.

The research results is in accordance to the opinion of Bontis (2002), Chen et al (2007), and Abdolmohammadi (2005) who stated that if intellectual capital is a scalable resource, it can provide an increase in the company's competitive advantage. Similarly, Hsu (2006) who argued that intellectual capital has an influence on the company's competitive advantage. According to Wigg (in Zhou and Dieter Fink, 2003), if the intellectual capital is correctly utilized and properly exploited, it would be successful and excelled in competition. Then Barney (2002) also argues that the intangible assets can improve the tangible performance of companies, which in turn can be a competitive advantage if some of those important assetsare intellectual capital. Finally, according to Amiri et al (2010), intellectual capital can be used to achieve the company's competitive advantage.

\section{The Influence of Knowledge Management on Competitive Advantage through Intellectual Capital in the Private Universities}

By knowing the influence of knowledge management towards intellectual capital, and the influence of intellectual capital towards competitive advantage, thus the calculation on the influence of knowledge management towards competitive advantage through intellectual capital could be performed. This is equals to $0.737 \mathrm{x} 0.924=0.681$ of standard deviation. The total effect is $0.6812=46.4 \%$, which means that any changes to the competitive advantage of PTS Kopertis Region IV can be caused by the knowledge management through its intellectual capital, which is $46.4 \%$. This can also mean that the synergies between knowledge management and intellectual capital can give a large influence on the improvement of competitive advantage in the private universities (see Figure 1).

If Private Universities conducts effective knowledge management activities, i.e.non-academic training of "customer service", then the non-academic skill increases. This can further improve the service quality, which is running service that is faster, more accurate and more satisfying, such as registration service, academic advising, transcripts, thesis supervising, class schedules, and others, as well as the increase in infrastructures and facilities related services. This research result is consistent with the opinions expressed by De Nisi (2009) that knowledge management is essential in order to achieve the company's sustainable competitive advantage where intellectual capital is as an intervention or mediation and will provide a more meaningful effect. From the research results conducted by Hsu (2006), there is a similar opinion that knowledge management has an influence on the company's competitive advantage by firstly increasing the intellectual capital. Similarly is the opinion of Zhou and Dieter Fink (2003) who stated that knowledge management will provide a more meaningful competitive advantage by increasing its intellectual capital.

\subsection{CONCLUSION}

By the description above, it can be concluded that the knowledge management of intellectual capital significantly influence on the PTS Kopertis Region IV. This means that the changes that occur in the intellectual capital are the result/response of any changes in knowledge management. Furthermore, intellectual capital significantly influences competitive advantage in the PTS Kopertis Region IV. This is means that if the intellectual capital has increased, i.e. in human capital, structural capital and customer capital, it can increase the competitive advantage PTS Kopertis Region IV, such as excelling in the innovation of product, process and management, to improve the quality of service as well as the achievement of a more efficient cost. Finally, synergies between knowledge management and intellectual capital can have a large impact on the improvement of competitive advantage in the PTS Kopertis Region IV. 


\section{References}

Abdolmohammadi, Mohammad J. (2005). The Components of Intellectual Capital For Accounting Measurement, Available Online at :www.sbaer.lka.edu/research/1999/wdsi/99wds.024.htm

Akhmadi, Hari (2008) 800 PTS Closed. From Kompas:http://www.kompas.com/read/xml/2008/08/01/10552722/800.pts.gulung.tikar

Amiri, Ali Naghi, GholmrezaJandghi, Seyed Mehdi Alvani, Reza Hosnavi, MajidRamezan. (2010). Increasing the Intellectual Capital in Organization: Examining the Role of Organizational Learning,European Journal of Social Sciences. 14(1), 98-108.

Aulawi, Hilmi (2009) Infrastructure Development Knowledge to Improve of Innovation Capability. PascasarjanaInstitutTeknologi Bandung

Barney, J. B \& Hansen, M. H. (2002). Trustworthiness as A Source of Competitive Advantage. Strategic Management Journal, 15, 175-190

Birkinsaw, J. \& Sheehan, T (2002).Managing the Knowledge of Life Cycle. Sloan Management Review, 44(1), 75-84

Bontis, N.(2002). Intellectual Capital: an Explorety Study That Develops Measures and Models. In C.W. Choo, N. Bontis (Eds.).The Strategic Management of Intellectual Capital and Organizational Knowledge. NY: Oxford University Press.

Carlucci, D. And Marr, B.(2004).The Knowledge Value Chain: How Intellectual Capital Impacts On Business Performance. Int. Journal Of Technology Management, 27(6), 575-590

Chen, Chunf Jen \& Jing Wen Huang. (2007). How Organizational Climate and Structure Affect Knowledge Management-The Social Interaction Perspective; International Journal of Information Management, 27, 104-118.

Dalkir, K (2005).Knowledge Management in Theory and Practice, United Kingdom, Elsevier Butterworth-Heinemann

DeNisi, A.S., Hitt, M.A. \& Jackson, S.E. (2009). The Knowledge-Based Approach to Sustainable. In Jackson, S.E., DeNisi, A. \& Hitt, M.A. (Eds.). Managing Knowledge

for Sustained Competitive Advantage. San Fransisco, CA: Jossey-Bass.Dessler, Gary (2007). Human Resource Management, Prentice-Hall, Inc. Upper Saddle River, New Jersey.

Dyer, L. et. al.(2006). AStrategy of Human Resource Management, In Dyer, L. (eds), Human Resource Management: Roles and Responsibilities, American Society for Personell and Bureau of National Affairs, Washington, DC, 1-34

Gregory, Howard (2010). KM-An Introduction-Simulation Educator-The Wasson Center.April, 5. www.slideshare.net/hgregory/km-introduction-powerpoint

Hsu, HsiuYueh (2006)Knowledge Management and Intellectual Capital, A Dissertation Submitted in Partial Fulfillment of the Requirement for the Doctoral og Philosophy, UMI Microform 321502

http://answer.ask.com/business/Management_and_HR/

Indiyati, Dian (2012), The Influence of Organizational Culture and Knowledge Management on the Intellectual Capital and its Impacts on Competitive Advantage, Dissertation.

Kompas (2008). 800 PTS Gulung Tikar. From Kompas: http://nasional.kompas.com/read/2008/08/01/10552722/800.pts.gulung.tikarKotler, P. (2010). Marketing Management, The Mollenium Edition, Prentice HaalInternational ,Unc., Upper Saddle River, New Jersey

Kuang, Shih Hsun, Chia Jung Chang \&Binshan Lin. (2010).Assessing Knowledge Creation and Intellectual Capital in Banking Industry. Journal of Intellectual Capital, 11(1), 74-89.

Liao, S.H., Fei, W.C. \& Chen, C.C (2007).Knowledge Sharing, Absorptive Capacity and Innovation Capability; An Empirical Study of Taiwans Knowledge-Intensive Industries. Journal Of Information Science, 20(10), 1-20

Nguyen, QueThiNguyet, Philip A Neck, ThanhHai Nguyen (2009). The Critical Role of Knowledge Management in Achieving and Sustaining Organizational Competitive Advantage; International Business Research, 2(3), 3-16.

Noe, Raymond A, Jason A. Colquitt, Marcia J. Simmering, \& Sharon A. Alvarez (2003). Knowledge Management Developing Intellectual and Social Capital; Managing Knowledge for Sustained Competitive Advantage

Noe, Raymond A, John R. Hollenbeck, Barry Gerhart\&Patrck M. Wright (2010). Human Resources Management: Gaining a Competitive Advantage, ${ }^{\text {th }}$ edition, McGraw-Hill/Irwin, New York

Nonaka, Ikujiro\& Konno, N (2007). The Concept of Ba: Building a Foundation for Knowledge Creation. California Management Review, 40(3), 40-54

Pike, S., Rylander, A., \&Roos, Goran. (2002). Intellectual Capital: Management and Disclosure. In C.W. Choo, \& N. Bontis (eds.) The Strategic Management of Intellectual Capital and Organizational Knowledge. NY: Oxford University Press

Quink, Ute. (2008). An Exploration of Knowledge Management and Intellectual Capital in a Nonprofit Organization Context, Thesis, Queensland University of Technology (QUT).

Ramadhan, Wael. H. (2010). The Influence of Organizational Culture on Sustainable Competitive Advantage Of Small and Medium Sized Establismen.

Schuler, Randall., S. \& Susan E. Jackson (2006). Linking Competitive Strategies with Human Resource Management Practice,The Academy of Management, 1(3), 207219

Stewart, Thomas A (1994). Intellectual Capital; Bantam Doubleday Dell Publishing Group, Inc, New York

Syaiful (2007). An Analysis Main Factor Influencing Demand in Knowledge Sharing (A case study: PT. Telekomunikasi Indonesia, TBK),InstitutTeknologi Bandung

Szulanski, G. (2003). Sticky Knowledge: Barriers to Knowing in The Firm, Great Britain: Sage Publications

Webometrics (2010) Ranking Web of Universities: Indonesia. From: http://www.webometrics.info/en/Asia/Indonesia\%20.

Zhou, Albert Z \& Dieter Fink (2003). The Intellectual Capital Web A Systematic Linking of Intellectual Capital and Knowledge Management: Journal of Intellectual Capital ,4(1), 34-48.

Zuhal (2010). Knowledge and Innovation : Platform to Competitive; PT GramediaPustakaUtama 